\title{
Religion og 'evolution'
}

\author{
Om religionens udvikling, indvikling og afvikling
}

JEPPE SINDING JENSEN

ENGLISH ABSTRACT: In the broad perspective, religion appears to have had a natural history or evolution: there were beginnings, countless changes over time and, presumably, there will be terminations. Evolution, however, has been a tabooed theme in the study of religion during most of the $20^{\text {th }}$ century, but this is now changing. It should be noted that is not unproblematic to use terms such as 'evolution' and 'religion' so a certain measure of philosophical consideration is called for in order to avoid reifications and over-simplifications. In the case of 'religion and evolution' it is unclear which elements and mechanisms can actually be said to have evolved and how it is at all meaningful to talk about group level evolution. In this article, it is pointed out that in the case of religion it is more likely (as far as the empirical evidence goes) that the changes over time point in the direction of complexity and differentiation. This seems to be a general condition for social and cultural institutions. One important factor in this history of human consciousness is symbolic externalization, not least made possible by writing. Here, I bring in the grand hypothesis of the Canadian psychologist Merlin Donald on the development of human consciousness and the concomitant theory about 'hybrid minds', that is, humans as both biological and cultural beings with a consciousness that reaches beyond the individual. The kind of reflexive consciousness, that this may entail, i.e., the growth of those mechanism which contribute to the 'cognitive governance', may cause religious communities of interpretation to critical awareness and to create tendencies towards secularization. Through the dissolution of religion by way of critical awareness the way may be paved for the possibility of new kinds of research into the mental world of humankind, e.g. in moral psychology, and so create the backdrop for a scientifically validated and partially normatively reasoned view of humanity. 
DANSK RESUMÉ: I et meget bredt perspektiv synes religionen at have en generel historie eller evolution: der er begyndelser, en mængde forandringer over tid og, formodentlig, afslutninger. Evolution har dog været et tabuiseret tema $i$ det meste af det 20. århundredes religionsforskning, men det er ved at ændre sig. Det er dog ikke uproblematisk at bruge begreber som 'evolution' og 'religion', og en vis videnskabsteoretisk og filosofisk omhu vil være nødvendig for at undgå reifikationer og forsimplinger. I tilfældet 'religion og evolution' handler det om, hvilke elementer og mekanismer som reelt kan siges at være evolverede, og om hvordan det giver mening at tale om evolution på gruppeniveau. I artiklen påpeges det, at der i tilfxldet religion (så vidt det empiriske materiale rækker) er tale om forandringer over tid, der går i retning af komplikation og differentiering. Dette synes at gælde generelt for sociale og kulturelle institutioner. En væsentlig faktor $i$ denne bevidsthedens historie er den symbolske eksternalisering, som ikke mindst skriftlighed har muliggjort. Her inddrages den canadiske psykolog Merlin Donalds store hypotese om den menneskelige bevidstheds historie og den tilhørende teori om 'hybrid minds': mennesket som både biologisk og kulturelt væsen, med en bevidsthed som rækker ud over individet. Den refleksive bevidsthed, som dette kan medføre, nemlig udviklingen af de mekanismer, som indgår i den 'kognitive styring', bevirker, at religiøse tolkningssamfund kan blive mere kritisk bevidste og udvikler sekulariseringstendenser. Ved religionens opløsning gennem den kritiske bevidsthed er der mulighed for, at ny forskning i menneskets mentale verden, f.eks. i moralpsykologien, kan danne baggrund for et videnskabeligt funderet og til dels normativt begrundet menneskesyn.

Keywords: Religion, Culture, Evolution, Conceptual realism, Cognitive governance, Secularisation

The triumph of consciousness will be complete when it can finally reflect on the collective process itself and see only itself, in the mirror of its own reflection ${ }^{1}$

\section{Religionshistorisk omvendelse}

Religionsvidenskabeligt Tidsskrift 56 havde temaet: "Evolution i religionsvidenskaben". Som flere af bidragyderne gør opmærksom på, har evolution, alt efter synsvinklen, været et omdiskuteret tema, begreb eller ligefrem problem i religionsforskningen. Ikke

1 Donald 2001, 326. Slutbemærkningen om 'The Evolution of human Consciousness' - undertitlen i A Mind So Rare. 
mindst i religionshistorien, hvor man ellers (i overensstemmelse med betegnelsen 'historisk') burde have forventet et forskningsparadigme, som ville lægge vægt på historie, udvikling og, i sidste instans, evolution. Sådan har det ikke været. Evolution blev et tabuiseret tema igennem det mest af det 20. århundredes religionsforskning, ligesom i det meste af humaniora og socialvidenskaberne. Det var kolonialismens, social-darwinismens og etnocentrismens virkninger, som skulle forhindres i at gentage sig, politisk såvel som intellektuelt og akademisk. Nu, efter årtier med radikal socialkonstruktionisme, postmodernisme og post-kolonialisme, er det igen (visse steder, som f.eks. i Danmark) blevet muligt at tale om evolution, også i forhold til religion. Efter selv at have været grebet af anti-evolutionismens ånd ser jeg dette skift som et fremskridt, såvel ideologisk som teoretisk og metodisk. Derfor, når jeg kommer frem til denne artikels konklusioner, er det i modstrid med mine tidligere overbevisninger, og konklusionerne er således ikke styret af forudfattede fordomme, men af indsigter, som dårligt lader sig tilbagevise. Når jeg bruger ordet 'indsigter', og ikke 'empiriske beviser', er det, fordi det forekommer usandsynligt, at der skulle kunne fremskaffes konkret evidens for konklusionerne, og den givne evidens vil i sagens natur ikke kunne gentages, da historien har gået sin gang. Konklusionerne er allerede antydet i citatet fra Merlin Donald: Når vi ser på religionernes individuelle historier og deres forløb, med alt hvad det indebærer af uddøde eller fusionerede religioner, så tyder alt på en forandring i retning af større kompleksitet og større refleksivitet. Kort sagt, religioner, betragtet som semantiske universer, bliver mere selvbevidste og dermed mere kognitivt og refleksivt komplekse. Paradoksalt nok ser det så også ud, som om vejen dermed er banet for, at de mere eller mindre forsvinder. Det skal jeg her forsøge at belyse.

At religioner og dermed også religion som generelt menneskeligt fænomen med tiden har undergået forandringer mod mere komplekse former, er en indsigt, som nok vil forekomme indlysende for de fleste i en moderne sekulariseret virkelighed. ${ }^{2}$ For er da ikke f.eks. Zen-Buddhisme eller protestantisk kristendom mere 'avanceret' end de skriftløse 'naturfolks' religioner? Det er en meget udbredt formodning eller opfattelse i moderne, offentlig diskurs, som baseres på ganske almindelig vestlig fremskridtsoptimisme og kulturel overlegenhedsfølelse. Det synes indiskutabelt, at nogle religioner er mere avancerede end andre. Det er bare ikke noget, som religionshistorikere har kunnet lide at høre, og dét af flere grunde. For det første er det en 'etnocentrisk' opfattelse, fordi den sædvanligvis tager udgangspunkt i egne forudfattede værdier og normer om udvikling og 'historiens gang'. For det andet kan sådanne vurderinger være baseret på almindelig ukendskab til religionerne og dermed fejlagtige. For det tredje kan ideer og spørgsmål om religionernes niveau og værdi siges at være f.eks. et teologisk anliggende og ikke et videnskabeligt, for hvilken målestok skulle kunne have universal gyldighed? Yderligere var det som oftest indlysende, at de, som talte om religioners niveau eller værdi, var ude i et apologetisk ærinde, hvor deres egen religion måtte være den mest værdifulde. Eller knapt så elegant formuleret: Det var jo kristne

2 Der er ingen grund til her at differentiere det moderne ud i hhv. 'sen-' eller 'post-'. 
teologer, som hævdede, at kristendommen var den mest overlegne religion. For en religionshistoriker (eller antropolog) var alle religioner 'lige gode', så værdi-argumenter var normativt, apologetisk, religiøst nonsens og i bedste fald kildemateriale til studier i fejlagtige og selvovervurderende forestillinger om transcendent legitimation. ${ }^{3}$ Normative argumenter om religioners niveau var ikke noget, man kunne tage alvorligt som videnskabelige udsagn. Men nu er jeg overbevist om, at man både teoretisk kan og metodisk bør klassificere religioner i typer, afhængigt af deres karakteristika. Klassifikationen drives således ikke af religiøst-dogmatiske, men af noget mere uvildige, videnskabelige grunde, især indsigter fra kognitionsvidenskabeligt hold og nogle dertil mere filosofiske overvejelser om udviklinger i den menneskelige tilværelses vilkår i retning af større autonomi. ${ }^{4}$ Når man derfor nu kan sige, at de teologiske standpunkter vedrørende religionernes forskellighed og 'rangordning' på sin vis var rigtige, så var det dog af fejlagtige grunde. Det er grund nok til at tage sagen op igen og på et andet grundlag. Og helt uden åbenbarings-teologiske 'sandhedsprætentioner' .

\section{Nogle teoretiske og terminologiske overvejelser over begreberne 'evolution' og 'religion'}

Når 'evolution' i denne artikels titel er sat i anførselstegn, er det, fordi det slet ikke er sikkert, at man kan tale om 'religionens' eller 'religionernes' evolution og heller ikke en hvilken som helst faktisk religions 'evolution' (gælder for både levende eller døde religioner). Det er bedre helt neutralt at tale om forandring, fordi der ikke for religion(er)s vedkommende er tale om evolution i streng videnskabelig forstand. Betegnelsen 'diakron genese' er nok det mest passende, men det er også ubrugeligt indtil videre. Man kunne også tale om 'udvikling', hvad rigtigt mange gør uden at tænke nærmere over det. Men begrebet 'udvikling' indebærer associationer til komplicerede filosofiske og teleologiske ideer og dermed også ideer om 'essenser' og 'tilsynekomster', noget som 'vikles ud' og åbenbarer sin sande natur. I første omgang er dette nok bedst at undgå, selvom citatet af Merlin Donald kunne ligne en kognitionspsykologisk validering af Hegels tanker.

Terminologiske vanskeligheder er der nok af, både hvad angår vores (A) religion og (B) evolution. Hvad angår 'A', skal man være klar over, at 'religion' er et begreb. Man kunne så tale om begrebets udvikling, men nok ikke om dets 'evolution', for det ville lyde besynderligt, måske ligefrem komisk, at tale om et begrebs 'evolution'. Begrebet 'religions'-historie er religionsforskningens vidnesbyrd om: Hvad var 'religion',

3 Den Hollandske Katekismus for Voksne (1970, 27-34) har korte, instruktive afsnit om den romersk katolske kirkes syn på graden af 'sandhed' i andre religioner efter II Vatikanerkoncil i 1962-1965 En i dansk sammenhæng kendt og bemærkelsesværdig teologisk variant er den, som siger, at kristendommen (altså i den rigtige og sande version i dialektisk teologi) slet ikke er en religion, og dermed er al religion overlegen.

4 F.eks.: "Human freedom is not an illusion; it is an objective phenomenon, distinct from all other biological conditions and found in only one species, us" (Dennett 2003, 305). 
og hvad er 'religion' siden hen blevet til? Det samme gælder for vogne, landsbyer, køkkener og mange andre menneskelige historiske produkter. Religion er ikke nogen enkeltorganisme; ingen sui generis-dannelse eller nogen 'natural kind', men en 'cultural kind', nemlig et begreb der er vokset ud af en konsensus, først i Europa, og som nu bruges i stort set hele verden. Det bevirker så på den anden side, at man på grund af almene, kognitive processer kan være tilbøjelig til at reificere religion og opfatte begrebet, som var det en ting. ${ }^{5}$ Jeg vil derfor i resten af denne artikel ofte bruge den noget irriterende notation 'Religion ${ }^{\circledR}$ ' ('religion reificeret'), fordi den minder os om, at det er noget i retning af et registreret varemærke og noget, som sagtens kunne have heddet noget andet. ' 'Religion' er, som Pascal Boyer meget rigtigt har sagt, et 'grumset emne' (an 'impure subject'), netop fordi der indgår så mange delelementer i det analytiske konstrukt, som vi normalt omtaler og forstår som 'religion' (Boyer 1996). Derfor vil Boyer nødigt tale om religionens evolution eller udvikling, men snarere om dele, elementer og aspekter af 'religion', som f.eks. modintuitive forestillinger om imaginære ,overmenneskelige agenter, ideer om liv efter døden og om ritualers Obsessive-Compulsive Disorder-lignende former (Boyer 2001, 238-240). Så når vi taler om 'religion', skal det være med en vis epistemisk omhu.

Diskussionerne om religions-evolution lå ganske stille i mange år; men de fik fornyet styrke dels med Walter Burkert's skelsættende Creation of the Sacred (1996), dels med en 'neo-darwinistisk' vending i kognitionsteoretisk orienteret forskning i kultur og religion, som var inspireret af nye tiltag i den evolutionære psykologi. ${ }^{7}$ Ved hjælp af 'reverse engineering' kunne man 'baglæns' regne sig til eller forestille sig, hvordan det måtte have foregået: fra vore forfædres tid på savannen og frem. Det har så til gengæld ført til en uløst diskussion om (1), at religion ${ }^{\circledR}$ er udviklet ('evolveret') som en adaptiv fordel for menneskelige grupper, fordi den fremmer koordination og kooperation eller (2), om religion ${ }^{\circledR}$ er et tilfældigt og ikke-intenderet bi-produkt af udviklingen af andre menneskelige træk og egenskaber - herunder en noget livlig forestillingsevne. Diskussionen er ikke afsluttet, og den bliver det nok heller ikke foreløbig. ${ }^{8}$ Religion ${ }^{\circledR}$ er en analytisk kategori, en konstruktion, som tjener forskningen til at fokusere på komplekse

5 Kirsten Hastrup omtaler denne proces som ontisk eller ontologisk 'dumping' (med henvisning til psykologen Carol Feldman 1987): "In short, the process of understanding itself transforms an inherently epistemological process to an ontological entity. If notions such as 'society' or 'religion' start as attempts at understanding specific and very varied phenomena, they end up as 'things' or ontological entities, that scholars have a hard time dissolving afterwards" $(2004,259)$.

6 Der har været megen diskussion i religionsforskningen om begrebets rigtighed. Jeg vil nøjes med at henvise til dets almindelige brugbarhed i forskningen. Vi har endnu ikke set noget universitet med et 'Department for the Study of the "Impure Subject" Formerly Called "Religion"'.

7 Ud over Boyer, se f.eks. Sperber 1996; Pyysiäinen 2003; Sinding Jensen 2009. Se også Geertz om dette problem (2011, 45-51) Man skal huske, at biologi og evolution var (stort set) 'ikke-temaer' i (f.eks.) kulturrelativistisk antropologi og religionsforskning i sidste halvdel af det 20. århundrede.

8 Der er efterhånden en del litteratur om den sag, se f.eks. Pyysiäinen og Hauser (2010) for diskussion og henvisninger. Efter min overbevisning er debatten 'grumset' på grund af især uklar teori og terminologi, men også på grund af polemiske holdninger mod eller for religion (især i kulturkampen i USA), se f.eks. Bulbulia et al. 2008 . 
sammenhænge mellem en række delementer og deres funktioner. Derfor kan man ikke lave computer-simuleringer om hverken forhistorisk evolution eller den historiske forandring af religion ${ }^{\circledR}$ som sådan, ganske enkelt fordi religion er et begreb og ikke er noget stabilt sæt af elementer. ${ }^{9}$ Psykologen Quentin Atkinson har i de seneste år forsøgt at udvikle en computer-simulations-model, der skulle kunne arbejde 'baglæns' og føre frem til en model af den oprindelige religion. ${ }^{10}$ Men det duer ikke. Man kunne lige så godt have forsøgt at lave en model af den 'oprindelige landsby'; enhver arkæolog vil vide, hvor håbløs den idé er. Der mangler ganske enkelt et robust korpus af enheder, der kan selekteres. Problemet er i al væsentlighed, at når det handler om et så komplekst fænomen som religion ${ }^{\circledR}$, er det uklart, hvad der skal ses som selektionsenheder. Er det gener, individuelle fænotyper, grupper, ideer, forestillinger, semiotiske produkter, adfærdsmønstre eller den ganske menneskehed, som er de enheder, der evolverer, er adaptive eller mal-adaptive? Hvilke er f.eks. de generative og selektive mekanismer? Og det går altså ikke længere med antagelser om 'Homo religiosus' som den generative mekanisme og geografiske og kulturelle mekanismer som selektive, selv om det faktisk kan tage sig sådan ud. I det hele taget er det problematisk at overføre biologisk evolutionsteori på analyse af menneskelig adfærd, ikke mindst når det handler om sociale og kulturelle niveauer.

Alligevel ligger tanken lige for, da det er indlysende, at det kan gavne f.eks. en gruppe, at dens medlemmer kan samarbejde og helst gøre det bedre end andre grupper. Og det er der eksempler på fra religionernes historie. Charles Darwin udtrykte selv ideen i gruppe-selektion således:

It must not be forgotten that although a high standard of morality gives but a slight advantage to each individual man and his children over the other men of the same tribe, yet that an advancement in the standard of morality and in increase in the number of well-endowed men will certainly give an immense advantage to one tribe over another. There can be no doubt that a tribe including many members who, from possessing in a high degree the spirit of patriotism, fidelity, obedience, courage, and sympathy, were always ready to give aid to each other and to sacrifice themselves for the common good, would be victorious over other tribes; and this would be natural selection (Darwin 1871, 166).

Kulturel og social evolution forekommer derfor at være ganske fornuftige forklaringer på udviklingen i meget menneskelig adfærd: Det enkelte individs gener har måske ikke nogen direkte fordel; men det har gruppens. ${ }^{11}$ Men lige præcis hvad der arves,

9 Clifford Geertz omtalte engang empirikerens drøm om data som 'things found glistering on the beach.'

10 Dette er et (noget dubiøst) eksempel på 'reverse engineering'; men med computer-simulering skulle det blive ekstra overbevisende. Ideen i Atkinsons projekt var sin enkelhed at finde et 'noget', der er i alle religioner og som så må anses for det 'oprindelige'. Noget sådant er også tidligere forsøgt udtænkt af Rudolf Otto, Gerardus van der Leeuw, Mircea Eliade m.fl.

11 Man kan her også tænke på mange religiøse gruppers krav (eller i det mindste forventninger) om endogami, 
hvem eller hvad det er til gavn for, hvilke selektionsmekanismer, der er operative - det er genstand for megen debat (Richerson og Boyd 2006; Lewens 2008). Forskerne er aldeles ikke enige, og selvom der kan fremkomme, hvad der synes at være overbevisende resultater, siges der også temmelig meget sludder, som påpeget af de to Cambridge-zoologer Kevin Laland og Gillian Brown i deres meget instruktive analyse af forskellige tilgange til evolutionære studier af menneskelig adfærd (2003). ${ }^{12}$ Et mere forsigtigt og konstruktivt eksempel på, hvordan det kan gøres, leveres f.eks. af Candace Alcorta og Richard Sosis i deres idé om religion som et 'adaptivt kompleks'. De fokuserer eksplicit på fire specifikke sider af religion®: trossystemer med overnaturlige agenter og modintuitive begreber, fælles ritualer, skelnen mellem helligt og profant og puberteten som den optimale periode for religiøs transmission og reproduktion (Alcorta \& Sosis 2005).

Den forskning, som vi indtil videre har set om religion og evolution, er præget af problemer omkring definition og teoretisk elaboration af, hoilke enheder der faktisk evolverer, og hvordan der kan tales om evolution med alt, hvad det indebærer af biologiske og teoretiske forudsætninger. ${ }^{13}$ Kan man overhovedet bruge begrebet evolution om noget, som er (mere eller mindre) bevidste produkter af menneskelig intentionalitet? Fordrer idéen eller hypotesen om evolution ikke, at der er tale om 'blinde' mekanismer eller funktioner? Muligvis kan man forsvare en 'sproglig analogi', hvis man ser sproget som et system, der forandres af dets brugere, og uden at de ved det, og man kunne så lade noget tilsvarende gælde for religioner som sproglignende betydningsnetværk. De færreste mennesker i dag ved, hvorfor de taler, som de gør. Diskurser og myter lever på samme måde; men at tale om evolution i teoretisk forsvarlig forstand synes at kræve kvantificérbare data og muligheder for identifikationer af årsager og virkninger. ${ }^{14}$ Den hidtidige forskning i 'the evolution of religion' er desværre også præget af ureflekterede og teoretisk naive overførsler af etnocentriske og 'kristocentriske' religionsopfattelser. Begge dele forøger kompleksitetsniveauet, eller forvirringen, om man vil. ${ }^{15}$ Det er i øvrigt et problem, at en del af de involverede evolutionsteoretisk og evolutionspsykologisk orienterede forskere har et ret begrænset kendskab til religion og især til religionsforskning. Nogle af dem har en antropologisk baggrund, og det

nemlig at medlemmer gifter sig inden for gruppen (eller rekrutterer nye tilhængere / medlemmer via konvertering).

12 Ethvert seriøst forsøg på at tale om evolution i menneskelige samfund bør inddrage Stoczkowskis (2002) kritiske overvejelser.

13 Udgivelsen af David Sloan Wilson's bog Darwin's Cathedral i 2002 blev fulgt op af megen debat om, på hvilke måder religion kan siges at gavne gruppe-selektion og tilpasning på flere niveauer (dvs. ud over det genetiske). Diskussionen er bl.a. fortsat i Bulbulia et al., eds. 2008. Wilson organiserer et web-forum om evolution og religion (uden de teoretiske problemer, som optager mig her): http:/ /evolution.binghamton.edu/religion/.

14 Den type ambitioner havde mem-teoriens forsvarere; men det projekt har heller ikke bidraget med uigendrivelige, videnskabelige indsigter.

15 Se f.eks. Jesper Sørensens anmeldelse (2010) af Bulbulia et al., eds. 2008. 
hjælper; men en stor del synes at mene, at religion ${ }^{\circledR}$ som generelt fænomen må være det, som de husker fra deres søndagsskole.

\section{'Alle religioner er lige, men nogle er (måske) mere lige end andre'}

I slutningen af det 19. århundrede havde evolutionistisk antropologi og religionsforskning deres glansperiode. Religioner var i sandhed ikke lige, og evolutionsteori kunne forklare hvordan og hvorfor. For Edward B. Tylor og James G. Frazer, for eksempel, var det ganske indlysende, at religioner og kulturer kom til udtryk på vidt forskellige niveauer, og at de kunne indplaceres og rangordnes efter større eller mindre grad af barbari eller civilisation. Kolonimagternes ideologer kunne ikke have fået større opbakning, og også i teologien fik nogle smag for kulturel evolution, som syntes at kunne underbygge kristendommens overlegenhed. Det kunne f.eks. ske på en noget pudsig måde, som i 'the fulfilment thesis', nemlig ideen om den virtuelle, men skjulte Kristus i hinduismen, der så skulle realiseres. ${ }^{16}$ Det har ikke skortet på normativ propaganda for og imod udvikling i og af religion og kultur i de sidste hundrede år, såvel uden for religion ${ }^{\circledR}$ i det hele taget som inden for specifikke religioner. Såvel modernister som postmodernister har tænkt religioner som forskellige i kvalitet og niveau og det ofte, som om de kunne indplaceres på en tidslig skala. Endepunktet i denne 'udvikling' eller 'evolution' kunne så være enten en specifik religionsform, f.eks. Zen-buddhisme, Radical Orthodoxy eller religionens opløsning i fornuftssamfundet. ${ }^{17}$ Men det kan også se anderledes ud, nu da det ikke er så oplagt, at religion ${ }^{\circledR}$ er på vej ud af menneskehedens historie. Ifølge Émile Durkheims funktionalistiske synsvinkel er religion ${ }^{\circledR}$ en social institution, som overlever, fordi den udfylder menneskelige behov. Der er i den forstand ikke forskel på religioner, hvad enten de er enkle eller komplekse. Også i den mere nutidige kulturrelativistiske religionshistories optik er alle religioner lige gode (måske med undtagelse af forskerens eget yndede specialeområde). Denne lighedsideologi om religionerne og deres 'værdi' er tydeligt socialantropologisk inspireret. I forsøg på at bortmane enhver form for normativitet som udtryk for etnocentrisme og mental-kolonialisme har der nærmest været tale om kulturel 'anti-evolution'. Tværdisciplinær selv-censur gjorde det til et tabu-emne at tale om evolution i kultur, samfund og religion. Men forskellene forsvinder ikke af den grund, og det bliver vanskeligere at forklare og forstå dem.

16 Jf. Panikkar 1964.

17 Mit eget argument lægger sig på sin vis i forlængelse heraf, se nedenfor. Det modsatte, nemlig nostalgisk religionslængsel hos 'traditionalister', som f.eks. Mircea Eliade ser jeg bort fra her, da det er en helt anden sag. 


\section{Fra evolution til forvikling, udvikling og indvikling...}

Den almindelige sekulariseringstese er blevet udfordret i de seneste årtier, hvor religiøse grupper og manifestationer har taget til i omfang og styrke og ofte med voldsomme politiske og økonomiske konsekvenser. Tesen havde sin baggrund i en model, der var baseret på den europæiske historie, og som tog udgangspunkt i differentiering i forhold til samfunds- og teknologikompleksitet. Dermed forudsagde tesen, at teknologisk udvikling måtte føre til religionens ophør, dvs. til en fuldstændig sekularisering. Det er ikke helt gået sådan, og meget taler for, at religion $®$ ikke bare forsvinder af sig selv. ${ }^{18}$ De traditionelle koblinger mellem materiel kultur og immateriel kultur eller mellem 'basis og overbygning' (i marxistisk forstand) synes ikke at holde som forståelsesramme. Men samtidig er der en voksende grad af socio-kulturel differens på (næsten) globalt niveau, hvor individer, grupper eller kulturer reagerer positivt eller negativt på deres religiøse traditioners tilstand. Sociale og kulturelle systemer (dvs. inklusive politiske og religiøse) udfordrer hinanden, og det medvirker også til dannelse af interne problemer i systemerne. Teorier om samfundsmæssig segregation og systemteorier af forskellig orientering søger måder at beskrive, forklare og forstå disse tilstande på, og der er ingen tvivl om deres relevans for en tydning af den postkoloniale verden. ${ }^{19}$ Men uanset systemers kompleksitetsniveauer og evige forandring, kan man så med rette sige, at systemer er underlagt evolution - mere end som en metafor? Når samfund, sprog og kulturer forandrer sig, er det så 'evolution'? Hvad med litteratur, film eller måske økonomi? Historien viser med al tydelighed, at enheder, elementer, funktioner, strukturer og betydninger forandrer sig. Men på hvilken måde eller i hvilket omfang er der tale om evolution? Det lyder plausibelt at tale om evolution, også i kultur, samfund og religion ${ }^{\circledR}$, når det handler om relativt autonome systemer, f. eks. om Maringfolket på Ny Guinea; men hvordan kan forstå evangelisk-karismatisk kristendoms nye store indflydelse hos de brede masser i Latinamerika? Her må man spørge: Hvad tilpasser sig hvad? Er der nogen selektion og noget, som 'evolverer'? Hvem har gavn af det: bønderne og arbejderen, det lokale erhvervsliv, Paven og romerkirken, eller Jesus? Mon ikke det snarest er prædikanterne og deres autoritet, som har gavn af denne 'udvikling'?20

Hvis man overhovedet skal tale om en slags 'evolution', dvs. en form for forandring, som synes at ligge latent og inherent i de religiøse betydnings- og adfærdssystemer,

18 Mange apologeter har vejret morgenluft i de seneste årtier. Sandt er det, at religion ${ }^{\circledR}$ nu fylder mere i visse offentlige rum, hvor det før ikke var tilfældet. Religion ${ }^{\circledR}$ kan også omtolkes radikalt, så 'Gud' bliver resultatet af evolutions- og kompleksitetsteori som hos f.eks. Stuart Kaufmann: 'I will present a new view of a fully natural God and of the sacred, based on a new, emerging scientific worldview' (2008, ix). Lutter amerikanske 'plus-ord'.

19 Her skal ingen speciel teori-dannelse nævnes - de rækker fra Althusser til Zizek. Under alle omstændigheder er de genstand for megen akademisk såvel som offentlig debat, skoledannelse og rivalisering.

20 Der findes etniske grupper, som f.eks. har haft gavn af missionens ædruelighedpolitik; men det er stadig ikke evolution, der så er tale om. 
må det have at gøre med stigende grader af differentiering i menneskelig praksis. Men sådanne differentieringer må snarere ligge i den symbolske produktion end i den materielle produktion eller i den sociale reproduktion, det vil sige på det niveau, hvor vi finder forestillinger, værdier, normer, diskurser og mentaliteter. Når man ser på de symbolske produktioner og deres former blot i historisk tid, er forskellene meget store, og det er vanskeligt ikke at klassificere dem som mere eller mindre udviklede. Men det kan også lade sig gøre uden den normative valorisering, som fulgte med tidligere evolutionsteorier. Der er ingen grund til at ringeagte eller nedvurdere andre, som har haft den skæbne at leve i andre mentaliteter. Menneskets evne til at tænke har sandsynligvis været nogenlunde konstant i meget lang tid; men de epigenetiske muligheder og vilkår har været forskellige, dvs. der har været store forskelle på, hvad man havde at tænke med. ${ }^{21}$ Der er karakteren af og vilkårene for disse mentaliteters og diskursers konstruktion og brug, som Mary Douglas havde blik for i sit essay 'Primitive Worlds', hvor det netop er den symbolske differentiering, som anses for at være den afgørende faktor for, at menneskeslægten gradvist tænker mindre egocentrisk og mere allocentrisk, abstrakt og refleksivt (Douglas 1984). ${ }^{22}$ Et mere udførligt skema, som beskriver hovedtræk i en sådan 'bevidsthedens historie' på et kognitionspsykologisk grundlag, præsenteres af Merlin Donald (2001). Hvordan det i det hele taget har kunnet lade sig gøre at skubbe denne udvikling i gang, begrundes i det, som Donald kalder 'den langsomme proces'. Mennesker kan fastholde indtryk og forstå sociale processer, der er meget længere, end andre primater kan (Donald 2007). Tilmed har den menneskelige kognition både en individuel og en kollektiv side, for individer fungerer inden for kognitivtkulturelle netværk af information som for eksempel religion. Det er disse netværk, der i det hele taget fremmer den kognitive udvikling hos individet og kollektivet, som dermed kan udnytte netværkets oplagrede 'viden'. ${ }^{23}$

Donalds teori opererer med fire 'stadier', hvor der gradvist adderes, føjes et nyt lag og dets funktioner til de eksisterende: Det første lag er det episodiske, som vi i høj grad har til fælles med mange andre dyr, og hvor bevidstheden udgøres af en række enkelt indtryk, 'episodic event perceptions', som er de biologiske erfarings-enheder. Oven på dette lag ligger der tre kulturelt definerede niveauer, nemlig det mimetiske, som bygger på evnen til at danne 'action metaphor', det mytiske, som omhandler sprog og symbolske repræsentationer, og det teoretiske, der præges af eksterne symbolske teori-systemer, og som kendetegner moderne kultur (Donald 2001, 260).

21 Det var ideen om 'præ-logisk mentalitet', der (især) fik bragt Lucien Lévy-Bruhl i miskredit, fordi han syntes at hævde, at 'de primitive' tænkte som børn (1987 [1910]). Nærmere undersøgelse (dvs. læsning) viser, at hans metodiske fejltagelse bestod i, at han primært fandt det 'præ-logiske' i det religiøse liv hos de 'primitive' og sammenholdt det med sekulær og rationel tænkning i hans egen samtid. Et alment kendetegn ved religiøse verdener er netop, at de er præ-logiske i deres grundlæggende aksiomatik.

22 På dette punkt er det svært at undgå den forkætrede 'rekapitulationstese': at det enkelte barns ontogenetiske udvikling gentager menneskehedens generelle fylogenetiske udvikling.

23 "The Human brain relies on cultural input even to develop the basic cognitive capacities needed to gain access to that knowledge in the first place" (Donald 2007, 214). Omsat til praksis: Når man lærer at læse, kan man få adgang til kulturens skatkammer. 
Det hele bygges oven på neuro-biologiske funktioner på det episodiske niveau og med assistance fra den særlige kognitive evne, som bevirker, at mennesker er i stand til at sætte sig 'i den andens sted' og til at have 'vikarierende' erfaringer - såvel bevidst som ubevidst. Det er en kompetence, som styrkes ved tilegnelsen af sprog og de muligheder, som det giver for individets perspektiv-tagning og for at opfatte sig selv, som var hun 'en anden'. Dette er ikke bare en mulighed i sprogtilegnelsen, men faktisk også en nødvendighed, for at den overhovedet kan lykkes. På det mimetiske niveau handler det om de motoriske færdigheder og fænomenologiske erfaringer i fælles opmærksomhed, som den imitative praksis fordrer. På det mytiske niveau bidrager sproglig og narrativ kompetence (både kodning og afkodning) til dannelsen af fælles intentionalitet og dermed potentialet for distribueret kognition og i fællesskab at kunne alt fra at lege 'cowboy'dere og indianere' til at styre lufthavnens hyper-komplicerede trafikkontrol. Dette er religionsvidenskabeligt interessant, fordi vi kan se, hvordan det mytiske niveau dominerer i mundtlige (skriftløse) kulturer med narrativ tænkning og mimetiske ritualer. De individuelle og kollektive kognitive funktioner er underlagt en styring ('governance'), som udøves gennem brug af det mytiske univers, f.eks. med reference til en religiøs kosmologi. En overgangsform er traditionelle skriftsamfund, hvor den samme kosmologi dog udsættes for skriftlig fiksering og dermed kan blive et erkendelsesobjekt for teologisk og filosofisk bearbejdning - men stadig inden for rammerne af det mytiske univers. ${ }^{24}$ I det moderne afløses eller overlejres det symbolske og teologisk-filosofiske niveau med det teoretiske 'lag', som udgøres af videnskabelig indsigt og filosofisk refleksion gennem formaliseringer, teoretiske instrumenter og 'massive external storage' af viden og information. ${ }^{25}$ Denne (indtil videre) sidste periode er udpræget intellektualistisk og teoretisk orienteret. Man kan godt sige, at dette skema ligner Hegels - igen og dog på et ganske andet grundlag. På baggrund af Donalds teoridannelse vil jeg nedenfor hævde, at den bevægelse, som vi ser i 'udviklingen' hen til det teoretiske niveau, snarere er en 'indvikling' i retning af øget teoretisk kompetence, diskurskompleksitet og repræsentationel refleksivitet.

\section{Kognitiv styring, diskurstyper og tolkingssamfund}

I det følgende forlader jeg samfundsplanet og de konkrete sociale, politiske, tekniske og økonomiske sektorer og taler udelukkende på forestillings- og diskursniveau. Det gør jeg ud fra det aksiom, at vi som mennesker grundlæggende er styret af vore forestillinger i tænkning og adfærd. Naturvidenskabelige kolleger vil nok blive noget fortørnede over opstillingen af et sådant aksiom, fordi de vil mene, at de kun er styret af 'ren viden'. Men uden på nogen måde at ville forfalde til relativistisk 'humbug', så

24 Se Hans Jørgen Lundager Jensens bidrag (2011) om begrebet 'aksetid' og dets applikation på dette niveau i den globale kulturelle proces.

25 Det er et ultrakort og kommenteret referat af Donalds idé. 
viser den nyere tids videnskabsfilosofi og erkendelsesteori, at det ikke er helt så enkelt, som den 'rene empiriker' kunne ønske sig. ${ }^{26}$ Meget i vores verden er sociale konstruktioner, det gælder ikke mindst religion ${ }^{\circledR}$, og på det område er den kognitive styring gennem forestillinger et indlysende faktum, for de sociale konstruktioner er selv produkter af den kognitive styring. ${ }^{27}$ Man skal lige erindre, at konstruktionen af den sociale virkelighed ikke er det samme som den sociale konstruktion af virkeligheden.

Hvordan vi så forholder os til al den viden, er et interpretationsanliggende og ikke et erkendelsesteoretisk problem. Vore interpretationer hænger igen sammen med de mentaliteter, dvs. forestillinger, normer og diskurser, som er til rådighed for os, og som vi påvirkes af. Derfor er disse niveauer fuldstændigt afgørende for vores liv og verden. I den moderne verden, på det 'teoretiske stadium', bliver den kognitive styring både mere krævende og mere diffus på det teoretiske niveau. For eksempel er moralske spørgsmål ikke så enkle, som de engang var, og de diskursive hierarkier er flere og til tider i modstrid med hinanden. Det afhænger oftest af kontekst og situation, hvilke mentaliteter, dvs. forestillinger, normer og diskurser, der er mest magtfulde. Diskurser er det primære medium til at kommunikere vore interpretative udkast om verden $\mathrm{i}$ diskurstyper. De står dog ikke alene, for uden 'tolkningssamfund' er de magtesløse: der skal mennesker til at handle i relation til diskurserne. Derfor kan man som eksperiment forestille sig en kombination af tre diskurstyper: (1) religiøs, (2) videnskabelig og (3) offentlig diskurs (i nutiden primært via medierne) og tre slags tolkningssamfund: (a) traditionel-fundamentalistisk, (b) modernistisk og agnostisk-kritisk og (c) refleksivt 'anti-grundlags' ${ }^{28}$ Eksperimentet er da at blande tal og bogstaver, så man får gammelkendte mentaliteter, men også nye - og måske umulige. Kombinationen 1) og a) giver f.eks. konservativ amerikansk kristendom, hvor det kan være svært at få øje på evangeliet som kærlighedsbudskab. Tager man (3) og (a), får man klassisk (menings-) diktatur. Hvor der nok er udbredt konsensus om, at religiøs diskurs på mange epistemiske felter afløses af videnskabelig diskurs, kan det være vanskeligt at se mediediskurs som et skridt fremad for menneskeheden. Men i store dele af verden har tolkningssamfund af type (a) den indstilling, at diskurs (2) er et 'vestligt' påhit. Endnu et eksempel: tolkningssamfund c) vil f.eks. afsløre diskurs (3) som markedsøkonomiens mytologisering. Der er adskillige muligheder for typologisering. Men specielt én type er interessant, når der tales om religion ${ }^{\circledR}$ og 'indvikling', nemlig den type, hvor diskurs (1) tolkes i form (c), for dér finder vi religionens selvophævelse i det 'mere-end-moderne' - i et afkald på rigoristisk grundlagstænkning og uden legitimation fra uantastelige transcendente aksiomer. ${ }^{29}$ De religions-'indviklinger', som erkender religionskritikkens

26 Erkendelsesteoretisk kan jeg tilslutte mig den kritisk-realistiske position, der præsenteres af Boghossian 2007 og som opsummerer årtiers diskussioner om relativisme.

27 Se f.eks. hos Searle 2000.

28 Det engelske udtryk for denne filosofiske indstilling er 'anti-foundationalist', så det kan næsten ikke hedde andet på dansk. Om den bedst karakteriseres som post-moderne eller post-analytisk, afhænger af modtageren.

29 Antropologen Roy Rappaport kaldte dem meget passende 'Ultimate sacred postulates' (1999, 263 ). 
sociologiske, semiotiske og psykologiske indsigter, vil formentlig stå stærkere på langt sigt. De traditionelle religionsformer lover for meget, både som trøst og som protest, og det vil mange steder uundgåeligt føre til kritik og revolution, når resultaterne udebliver. ${ }^{30}$ På den anden side synes religion ${ }^{\circledR}$ at være et særdeles sejlivet kognitivt fænomen, som derfor vedvarende kan have afgørende social magt. Omvendt har den sociale magt stærk indvirkning på den menneskelige kognitions former og kollektive mentalitet. $^{31}$

Hvis, eller når, religion ${ }^{\circledR}$ 'classic' svækkes, så må andre instanser og funktioner tage over for at sikre, hvad religionen ud fra en funktionel bestemmelse så længe har været garant for. Religion ${ }^{\circledR}$ og dens funktioner transformeres og diffunderes ud og antager mange skikkelser (Sinding Jensen 2008, 139f.). Når religionen således diffunderes ud i den radikale modernitet, kan det synes, som om teologien dermed må blive meget 'tynd', når den ikke længere kan tale om Gud, men i stedet om det menneskelige liv, og når filosofien placerer det 'absolutte' i det dennesidige (Andersen 2009). Til gengæld bliver filosofien og den filosofiske teologi til en meget 'federe' antropologi, hvor mennesket og dets væsen kan tages op og reflekteres på baggrund også af videnskabelige indsigter. Når Jürgen Habermas for snart længe siden filosofisk kunne påpege, at hvor religionernes praksis traditionelt havde garanteret det socialt og kulturelt forbindtlige, og det forbindtlige i moderniteten så begrundes i sprogligheden, der kan man nu, en generation senere, også se konturerne af andre nye resultater om menneskets socialitet og i dette tilfælde hovedsagelig fra den eksperimentelle psykologi. Påfaldende ofte har filosofiske intuitioner og overvejelser senere vist sig at kunne underbygges videnskabeligt. Det gælder interessant nok også for moralen. ${ }^{32}$ I modsætning til, hvad mange har frygtet, er der ingen angst nødig for moralens fremtid. Den seneste moralpsykologi og -filosofi demonstrerer, hvordan og i hvor høj grad moral er 'indbygget' i os som art, individuelt, kollektivt og selv globalt (f.eks. Gazzaniga 2005. 2008; Hauser 2006). ${ }^{33}$ Moralen kan snildt klare sig uden religion. Det er en udbredt og almindelig antagelse, at religion ${ }^{\circledR}$ har bidraget med moral og etik; men noget tyder på, at det blandt andet er, fordi mennesket grundlæggende er et moralsk væsen, at religion® er 'evolveret' kulturelt. ${ }^{34}$

30 Det er ikke Islam, der kan løse f.eks. Libyens, Ægyptens eller Irans problemer.

31 Også her kunne man referere til et væld af samfundsvidenskabelig teoridannelse om magt og afmagt, men det må andre gøre.

32 Man kan næsten forestille sig K.E. Løgstrup filosofi valideret eksperimentelt i moralpsykologisk regi.

33 Det monumentale 3-binds værk redigeret af Sinnott-Armstrong (2008) demonstrerer omfanget af denne forskning. Seneste og meget interessante bidrag til diskussion af moral 'på biologisk' grundlag er Patricia Churchland 2011.

34 Dette er en foreløbig delkonklusion fra mit eget forskningsprojekt omkring 'normativ kognition' i religion og kultur, baseret især på forskning som refereret i foregående note. 


\section{Sekularisering - endnu en gang}

Kort sagt: Trods den opblomstring, som religion ${ }^{\circledR}$ (og ikke mindst dens politisk funktioner) kan synes at have haft i de seneste årtier, havde de tidligere sekulariseringteoretikere nok ret alligevel, og det havde de måske uden rigtigt at vide hvorfor. De iagttog, hvad der lignede en bestemt udvikling i en bestemt del af verden, og så fremskrev de den ud fra en tro på visse kulturformers tilsyneladende teknologiske, økonomiske og politiske indbyrdes sammenhæng og overlegenhed. Måske tog de fejl af årsagerne; men virkningen, nemlig ophævelsen af religion ${ }^{\circledR}$, synes uundgåelig, omend den nu forekommer at ligge ganske langt ud i fremtiden. Det er ubetvivleligt, at religion ${ }^{\circledR}$ kommer fra menneskets natur. Og religionens ophævelse kan også kun komme fra mennesket selv. Den individuelle og kollektive udvikling af menneskets er gennem historien blevet befordret af religiøse traditioner, på godt og ondt og slet ikke i nogen lineær progression. Men de funktioner, som religion ${ }^{\circledR}$ traditionelt har varetaget, kan varetages andre steder, på andre måder og af andre sociale og kulturelle 'mekanismer' . De to klassiske skikkelser i religionsforskningen, James G. Frazer og Émile Durkheim, sluttede hver især deres store værker med gisninger om, hvad der kunne blive religionens ${ }^{\circledR}$ afløsning. Det er derfor min hypotese, at en sådan afløsning nu, godt et hundrede år senere, kunne tegne til at blive en humanvidenskabeligt reflekteret og (tilmed til dels neurovidenskabeligt) baseret indsigt i mennesket som et socialt og kulturelt væsen, der har levet i virtuelle netværk siden den 'symbolske revolution' for mindst 50.000 år siden. Det betyder selvfølgelig ikke, at videnskaben nu definitivt kan tilbyde at dække alle behov, som mennesket måtte have for f.eks. værdier og mening. Men det, som videnskaben kan tilbyde, er en bedre indsigt i og begrundelse af, at menneskets liv, individuelt som kollektivt, har nogle dybe rødder, som det ville være katastrofalt ikke at være opmærksom på.

Menneskeheden har i sandhed fået 'A Mind So Rare'. Det synspunkt, som jeg forfægter her, vil for nogle ligne psykologisk reduktionisme og scientistisk optimisme; men det er en indlysende erfaring, at mennesket som art har fået muligheden for at transcendere sig selv (dvs. gå ud over den dyriske natur) igennem kulturen, og at videnskaberne nu i stadig højere grad er i stand til også refleksivt både at forklare og forstå dette mirakel. Denne indsigt giver mennesket en hidtil uset kritisk frihed og mulighed for selvrefleksion. Kritisk kognitiv frihed har normalt ikke været religionens anliggende, for en af religions ${ }^{\circledR}$ funktionelle kendetegn har traditionelt været den 'cognitive governance', der fik det religiøse perspektiv til at tage sig ud som det, der var 'the really real' og dermed basis for tolkningen af den oplevede verden (Geertz 1973, 112). Hvis der er rigtigt, at mennesket har ret til frihed, kritik og (selv-)indsigt, så er traditionel religion mere mod-menneskelig end medmenneskelig. Derfor vil den form for religion, der (hypotetisk) vil kunne tænke sig selv i forsvar for både kritik, frihed og indsigt, dermed også kunne eksternalisere den naturgivne menneskelighed (jfr. Donald, Gazzaniga, Hauser, Churchland m.fl.); men den vil sandsynligvis ikke ligne religion, som vi ellers har kendt det. Det bliver en sag for homo ludens, 'imaginens' 
og sapiens: mennesket som ved, at det leger; som ved, at det forestiller sig ting og sager; og som ved, at det ved det.

Verden synes (trods alt) at udvikle sig mod det bedre. Når verden med rette kan siges ikke at være det mest vidunderlige sted for alle, så er det ikke, fordi vi ikke ved, hvordan det skal være, men fordi nogle slipper af sted med at handle på måder, som alle ikke-patologiske mennesker dybest set og intuitivt ved, er forkerte. Det er en del af de erkendelser, som nyere videnskabelige tiltag inden for kognitionsforskning og forskellige psykologiske felter (evolution, social, udvikling og moral) har bibragt, og det er erkendelser, som fortjener at blive kendt og dermed også indgå i filosofiske og teologiske overvejelser. Det kommer ikke længere blot an på at citere andre filosoffer eller teologer. Det kommer an på at forandre.

\section{LITTERATUR}

Alcorta, Candace S. \& Richard Sosis

2005 "Ritual, Emotion, and Sacred Symbols. The Evolution of Religion as an Adaptive Complex", Human Nature 16 (4), 323-359.

Andersen, Vagn

2009 Transformationen Gottes. Abwandlungen des Begriffs des Unbedingten in der Moderne, Aarhus Universitetsforlag, Aarhus.

Boghossian, Paul

2007 Fear of Knowledge. Against Relativism and Constructivism, Oxford University Press, Oxford.

Boyer, Pascal

1996 "Religion as an impure subject: a note on cognitive order in religious representation in response to Brian Malley", Method \& Theory in the Study of Religion 8 (2), 201-213.

2001 Religion Explained: the evolutionary origins of religious thought, Basic Books, New York.

Brand, Paul, ed.

1970 Den hollandske Katekismus for Voksne, Kateketcentralens Forlag, København.

Bulbulia, Joseph et al., eds.

2008 The Evolution of Religion: Studies, Theories, and Critique, Collins Foundation Press, Santa Margarita, CA.

Burkert, Walter

1996 Creation of the Sacred. Tracks of Biology in Early Religions, Harvard University Press, Cambridge, MA.

Churchland, Patricia

2011 Braintrust: What Neuroscience Tells Us about Morality, Princeton University Press, Princeton.

Darwin, Charles

1871 The Descent of Man and Selection in Relation to Sex, John Murray, London.

Dennett, Daniel C.

2003 Freedom Evolves, Allen Lane, London.

Donald, Merlin

2001 A Mind So Rare. The Evolution of Human Consciousness, W.W. Norton, New York \& London.

2007 "The Slow Process: A hypothetical cognitive adaptation for distributed cognitive networks", Journal of Physiology-Paris 101, 214-222. 
Douglas, Mary

1984 "Primitive Worlds", in: idem., Purity and Danger: An Analysis of the Concepts of Pollution and Taboo, London, Routledge, 74-94

Feldman, Carol F.

1987 "Thought from language: the linguistic construction of cognitive representations", in: Jerome Bruner, \& Helen Haste, eds., Making Sense. The Child's Construction of the World, Methuen, London, 131-146.

Gazzaniga, Michael S.

2005 The Ethical Brain, Dana Press, New York.

2008 Human. The Science Behind What Makes Your Brain Unique, Harper Perennial, New York.

Geertz, Armin W.

2011 “Om religion og evolution: En introduktion", Religionsvidenskabeligt Tidsskrift 56, 23-60.

Geertz, Clifford

1973 The Interpretation of Cultures, Basic Books, New York.

Hastrup, Kirsten

2004 "Religion in Context. A Discussion of Ontological Dumping", in: Peter Antes, et al., eds., New Approaches to the Study of Religion, Vol. 1: Regional, Critical and Historical Approaches, Walter de Gruyter, Berlin \& New York, 253-270.

Hauser, Marc D.

2006 Moral Minds: How Nature Designed our Universal Sense of Right and Wrong, Harper Collins, New York.

Jensen, Hans J. Lundager

2011 "Religionshistorie og aksetid. Om Robert Bellahs udkast til en evolutionær religionshistorie", Religionsvidenskabeligt Tidsskrift 56, 5-22.

Kaufmann, Stuart A.

2008 Reinventing the Sacred. A New View of Science, Reason and Religion, Basic Books, New York.

Laland, Kevin N. \& Gillian R. Brown

2003 Sense \& Nonsense. Evolutionary perspectives on human behaviour, Oxford University Press, Oxford.

Lévy-Bruhl, Lucien

1987 How Natives Think, Princeton University Press, Princeton (fransk org. 1910).

Lewens, Tim

2008 "Cultural Evolution", Stanford Encyclopedia of Philosophy. http://plato.stanford.edu/entries/ evolution-cultural/ (set 2011-04-27)

Panikkar, Raimon

1964 The Unknown Christ of Hinduism, Darton, Longman \& Todd, London.

Pyysiäinen, Ilkka

2003 How Religion Works. Towards a New Cognitive Science of Religion, Brill, Leiden.

Rappaport, Roy A.

1999 Ritual and religion in the making of humankind. Cambridge University Press, Cambridge.

Richerson, Peter J. \& Robert Boyd

2006 Not by Genes Alone. How Culture Transformed Human Evolution, University of Chicago Press, Chicago.

Searle, John R.

2000 Mind, Language, and Society. Philosophy in the Real World, Phoenix, London.

Sinding Jensen, Jeppe

2008 "Religionskritik - i et globalt perspektiv", in: Peter Boe, ed., Religionskritik. En Antologi, Tiderne Skifter, København, 117-143.

2009 "Religion as the unintended product of brain functions in the 'standard cognitive science of religion model", in: Michael Stausberg, ed., Contemporary Theories of Religion. A critical Companion, Routledge, London, 129-155. 
Sinnott-Armstrong, Walter, ed.

2008 Moral Psychology, Vols. 1-3, Cambridge, MA. MIT Press.

Sperber, Dan

1996 Explaining Culture. A Naturalistic Approach, Blackwell, Oxford.

Stoczkowski, Wiktor

2002 Explaining Human Origins. Myth, Imagination and Conjecture, Cambridge University Press, Cambridge.

Sørensen, Jesper

2010 Anmelse af: Joseph Bulbuliaet al., eds.: The Evolution of Religion: Studies, Theories, and Critique, Temenos 45 (1), 121-124.

Wilson, David Sloan

2002 Darwin's Cathedral: Evolution, Religion and the Nature of Society, University of Chicago Press, Chicago.

Jeppe Sinding Jensen, lektor, dr. phil. Afdeling for Religionsvidenskab, Arabisk og Islamstudier

Faculty of Arts, Aarhus Universitet 